\title{
A Multicommuted Flow Procedure for the Determination of Total and Free Cholesterol in Eggs and Human Blood Serum by Chemiluminescence
}

\author{
Oldair D. Leite, ${ }^{a}$ Heberth J. Vieira, ${ }^{b}$ Orlando Fatibello-Filho ${ }^{c}$ and Fábio R. P. Rocha ${ }^{*, d}$ \\ anstituto de Ciências Ambientais e Desenvolvimento Sustentável, Universidade Federal da Bahia, \\ 47805-100 Barreiras-BA, Brazil
}

${ }^{b}$ Universidade Federal do Pampa, 96412-420 Bagé-RS, Brazil

${ }^{c}$ Departamento de Química, Universidade Federal de São Carlos, CP 676, 13560-970 São Carlos-SP, Brazil

${ }^{d}$ Centro de Energia Nuclear na Agricultura, Universidade de São Paulo, CP 96, 13400-970 Piracicaba-SP Brazil

\begin{abstract}
Um sistema de análises em fluxo com multicomutação com detecção por quimiluminescência foi desenvolvido para a determinação de colesterol livre e total sem alterações no módulo de análises. Colesterol estearase e colesterol oxidase foram imobilizadas em esferas de vidro via glutaraldeído/3-aminopropiletoxisilano e mini-colunas contendo as enzimas foram usadas para tratamento das amostras em linha. Ésteres de colesterol foram clivados a colesterol e ácidos graxos na coluna empacotada com colesterol estearase. No reator contendo colesterol oxidase, o analito foi convertido a 4-colesten-3-ona e peróxido de hidrogênio. A detecção foi baseada na quimiluminescência produzida por $\mathrm{H}_{2} \mathrm{O}_{2}$ no sistema hexacianoferrato(III)-luminol. Os efeitos de variáveis químicas e hidrodinâmicas sobre o sinal de quimiluminescência foram avaliados. As curvas analíticas foram lineares entre 250 e $2500 \mathrm{mg} \mathrm{L}^{-1}$ e 500 e $4000 \mathrm{mg} \mathrm{L}^{-1}$, para colesterol livre e total, respectivamente. Limites de detecção para ambos os analitos foram estimados em $60 \mathrm{mg} \mathrm{L}^{-1}\left(99,7 \%\right.$ de confiança). A frequência de amostragem foi de $55 \mathrm{~h}^{-1}$ e o consumo de reagentes foi de $350 \mu \mathrm{g}$ de luminol e $2,6 \mathrm{mg}$ de hexacianoferrato(III) de potássio por determinação. O procedimento desenvolvido foi aplicado à determinação de colesterol em ovos e soro sanguíneo humano gerando resultados concordantes com o procedimento espectrofotométrico de referência com nível de confiança de $95 \%$.
\end{abstract}

A multicommuted flow-based procedure with detection by chemiluminescence for the determination of total and free cholesterol without changes in the flow manifold is proposed. Cholesterol esterase and cholesterol oxidase were both immobilized on glass beads via glutaraldehyde/(3-aminopropyl)-triethoxysilane and mini-columns containing the enzymes were used for online sample treatment. Cholesterol esters were cleaved to cholesterol and fatty acids at the packed reactor containing cholesterol esterase. The reactor containing cholesterol oxidase converted cholesterol to cholest-4-en-3-one also yielding hydrogen peroxide. Detection was based on the chemiluminescence produced by $\mathrm{H}_{2} \mathrm{O}_{2}$ in the hexacyanoferrate(III)-luminol system. Influence of both chemical and hydrodynamic variables on the chemiluminescence signals were investigated. The analytical curves were linear from 250 to $2500 \mathrm{mg} \mathrm{L}^{-1}$ and from 500 to $4000 \mathrm{mg} \mathrm{L}^{-1}$, for free and total cholesterol, respectively. Detection limits for both analytes were estimated as $60 \mathrm{mg} \mathrm{L}^{-1}$ at $99.7 \%$ confidence level. The sampling rate was $55 \mathrm{~h}^{-1}$ and reagent consumption was $350 \mu \mathrm{g}$ of luminol and $2.6 \mathrm{mg}$ of potassium hexacyanoferrate(III) per determination. The procedure developed was successfully applied for determination of cholesterol in eggs and in human blood serum with results in agreement with the reference spectrophotometric method at the $95 \%$ confidence level.

Keywords: flow analysis, multicommutation, chemiluminescence, cholesterol, cholesterol esterase, cholesterol oxidase

*e-mail: frprocha@cena.usp.br 


\section{Introduction}

Cholesterol is a constituent of animal foods such as eggs and meat ${ }^{1,2}$ and excessive dietary uptake may hazardously increase its concentration in blood. ${ }^{3,4}$ Although small amounts are essential for the synthesis of hormones, high levels in blood increase the risks of heart diseases. Saturated fats rise cholesterol levels in blood while unsaturated fats contribute to its decrease.

The clinical analysis of cholesterol in serum samples is important in the diagnosis and prevention of a large number of clinical disorders such as hypertension and arteriosclerosis, with a clear correlation between total cholesterol in human blood serum and heart diseases. ${ }^{5}$ Several methods for cholesterol assay in biological samples and foods have been reported, including detection by spectrophotometry, ${ }^{4,6}$ amperometry, ${ }^{7,8}$ fluorimetry, ${ }^{9}$ potentiometry ${ }^{10}$ and chemiluminescence. ${ }^{11-13}$ In a previous work focusing on the flow-injection determination of total cholesterol in animal blood serum with detection by chemiluminescence, ${ }^{11}$ a solid-state detector of a commercial spectrophotometer was used for the analysis of offline diluted samples, thus making the analysis tedious and time consuming for a large lot of samples. Some works have focused the determination of both free and total cholesterol exploiting optical ${ }^{14,15}$ or amperometric ${ }^{16,17}$ detection.

Traditional analytical uses of chemiluminescence (CL) involve reactions that produce intense radiation emission that can be monitored with simple equipments. The light intensity is usually measured by a photomultiplier tube (PMT), ${ }^{13}$ but simpler and cheaper detectors like a photodiode can be used as well. ${ }^{18,19}$ The use of a photodiode detector and immobilized enzymes in flow systems present some relevant advantages such as simplicity, reliability, low-cost and lower reagent consumption. ${ }^{18,20}$

Multicommutation is a powerful alternative to increase the versatility of flow-based procedures, in which discrete commuting devices are employed for solution handling. ${ }^{21}$ This approach also presents the advantage of minimizing both reagent consumption and waste generation. ${ }^{21,22}$ Coupling a multicommuted flow procedure with chemiluminescence detection for the determination of cholesterol is thus an interesting alternative.

This paper reports on a CL system for the determination of total and free cholesterol in foods and human blood serum, based on the production of hydrogen peroxide by reaction of the analytes catalyzed by immobilized enzymes cholesterol esterase (ChE) and cholesterol oxidase (ChOx). The produced hydrogen peroxide oxidizes luminol in alkaline medium under catalysis of hexacyanoferrate(III) to produce the CL signals. The proposed procedure makes feasible the fast determination of both total and free cholesterol, minimizing costs, reagent consumption and waste generation.

\section{Experimental}

\section{Reagents and solutions}

All chemicals were of analytical-grade and solutions were prepared in deionized water obtained from a Millipore (Bedford, MA) Milli-Q system (model UV Plus UltraLow Organics Water). Cholesterol oxidase (ChOx) and cholesterol esterase (ChE) were purchased from Sigma (St. Louis, USA).

A $0.4 \mathrm{~mol} \mathrm{~L}^{-1}$ carbonate buffer solution was prepared by dissolving $10.6 \mathrm{~g}$ of $\mathrm{Na}_{2} \mathrm{CO}_{3}$ in water, the $\mathrm{pH}$ was adjusted to 11.0 with concentrated hydrochloric acid and the volume was made up to $250 \mathrm{~mL}$ with water. This solution was stored in an amber flask in the refrigerator at $4{ }^{\circ} \mathrm{C}$.

A $1.0 \times 10^{-2} \mathrm{~mol} \mathrm{~L}^{-1}$ luminol solution $\left(\mathrm{R}_{1}\right)$ was prepared by dissolving $443.0 \mathrm{mg}$ of 5-amino-2,3-dihydro-1,4phthalazinedione (Sigma) in $0.4 \mathrm{~mol} \mathrm{~L}^{-1}$ carbonate buffer solution at pH 11.0 and the volume was made up to $250 \mathrm{~mL}$ with the same buffer solution. This solution was stored in a refrigerator at $4{ }^{\circ} \mathrm{C}$ by three days before use..$^{23}$

A $0.1 \mathrm{~mol} \mathrm{~L}^{-1}$ potassium hexacyanoferrate(III) solution $\left(\mathrm{R}_{2}\right)$ was daily prepared by dissolving $3.290 \mathrm{~g}$ of the salt and making the volume to $100 \mathrm{~mL}$ with water. A $0.01 \mathrm{~mol} \mathrm{~L}^{-1}$ stock cholesterol solution was prepared in $0.05 \mathrm{~mol} \mathrm{~L}^{-1}$ phosphate buffer solution at $\mathrm{pH} 7.5$ also containing $10 \%(\mathrm{~m} / \mathrm{m})$ of Triton X-100 and $10 \%(\mathrm{~m} / \mathrm{m})$ isopropanol. This solution was heated at $65^{\circ} \mathrm{C}$ in a thermostated water bath for dissolution of cholesterol and was stable for at least 10 days when stored at $4{ }^{\circ} \mathrm{C}$ in the dark. Cholesterol reference solutions were prepared by dilution of the stock with $0.05 \mathrm{~mol} \mathrm{~L}^{-1}$ phosphate buffer solution. Solutions $4.5 \%(\mathrm{v} / \mathrm{v})$ (3-aminopropyl)triethoxysilane and $2.5 \%$ $(\mathrm{m} / \mathrm{v})$ glutaraldehyde were prepared in water by dilution of concentrated reagents.

A commercial kit used for the enzymatic determination of cholesterol was purchased from Labtest Diagnóstica (Lagoa Santa, MG, Brazil) and used in the reference procedure.

\section{Apparatus}

The multicommuted flow system consisted of a peristaltic pump (Ismatec, IPC-12) equipped with Tygon ${ }^{\mathrm{TM}}$ pumping tubes to propel the solutions, six three-way solenoid valves (NResearch, 161T031), polyethylene tubing (0.8 $\mathrm{mm}$ i.d.) and acrylic joint points. System 
control and data acquisition were performed with a Pentium $800 \mathrm{MHz}$ microcomputer equipped with a commercial electronic interface (National Instruments) and a lab-made electronic circuit similar to that previously described. ${ }^{24}$ The software was developed in Labview 7.0 (National Instruments) running under Windows XP.

Chemiluminescence measurements were carried out with a lab-made luminometer previously described. ${ }^{19}$ A spiral flow cell made of $100 \mathrm{~cm}$ coiled polyethylene tubing ( $c$. $500 \mu \mathrm{L}$ inner volume) was placed in front of a photodiode (OSD 50-E) of $100 \mathrm{~mm}^{2}$ sensitive area. The polyethylene tubing is transparent to the electromagnetic radiation emitted by the luminol/ $\mathrm{H}_{2} \mathrm{O}_{2}$ system (maximum within 420 and $440 \mathrm{~nm}$ ). The flow cell and photodiode were protected from ambient light using an acrylic dark box.

The determination of cholesterol using the commercial kit was carried out with a Femto 482 spectrophotometer (São Paulo, Brazil).

\section{Enzyme immobilization procedures}

Cholesterol esterase (ChE) and cholesterol oxidase (ChOx) enzymes were immobilized on controlled pore silica. The beads were initially prepared by silanization of silica with (3-aminopropyl)-triethoxysilane and activation of the support with glutaraldehyde. Enzymes were then covalently bonded to glutaraldehyde. ${ }^{25}$

Initially, $3 \mathrm{~mL}$ of $4.5 \%$ (v/v) (3-aminopropyl) triethoxysilane aqueous solution was added to a mass of $0.20 \mathrm{~g}$ of treated silica. Then, the inorganic support was coated with (aminoalkyl)silane for $40 \mathrm{~min}$ in a vacuum desiccator at $25^{\circ} \mathrm{C}$. After removing the excess of the solution, the modified silica was allowed to react with $5 \mathrm{~mL}$ of $2.5 \%(\mathrm{~m} / \mathrm{v})$ glutaraldehyde aqueous solution for $20 \mathrm{~min}$. After washing the modified silica with deionized water and $0.05 \mathrm{~mol} \mathrm{~L}^{-1}$ phosphate buffer solution at $\mathrm{pH} 7.0$, a mass of $25 \mathrm{mg}$ (120 U) of ChOx was coupled with residual aldehyde groups in phosphate buffer solution for $24 \mathrm{~h}$ at $4{ }^{\circ} \mathrm{C}$. This coupling reaction was monitored by determination of enzymatic activities of supernatant after reaction times of 4, 8, 12, 16 and $24 \mathrm{~h}$. For ChE, a mass of $3 \mathrm{mg}(25 \mathrm{U}$ ) was coupled with $0.20 \mathrm{~g}$ of pre-activated inorganic support as described for ChOx. Simultaneously, control experiments were carried out using $0.20 \mathrm{~g}$ of silica without activation at the same experimental conditions. So with the difference between the enzymatic activities obtained in each experiment it was possible to determine the amount of each enzyme immobilized (units of $\mathrm{ChE}$ or ChOx per gram of silica). For this purpose the protein content in the initial enzyme solution was determined before and after immobilization using the procedure described by Hartree. ${ }^{26}$ After that, the inorganic supports containing immobilized $\mathrm{ChE}$ and $\mathrm{ChOx}$ were washed with a $0.05 \mathrm{~mol} \mathrm{~L}^{-1}$ phosphate buffer solution in order to remove the excess of enzyme.

A mass of $200 \mathrm{mg}$ of each immobilized enzyme was packed into two glass tubes $(20 \mathrm{~mm} \times 3 \mathrm{~mm}$ i.d. $)$ and coupled to the multicommuted flow system. The columns with immobilized enzymes were stored in the same phosphate buffer solution at $4{ }^{\circ} \mathrm{C}$ when not in use.

\section{Sample preparation}

Samples of eggs were acquired at the local market. Egg yolks were ground to pass through a 40-mesh sieve. Extraction was carried out by direct saponification as previously reported. ${ }^{27} \mathrm{An}$ accurate mass of $500 \mathrm{mg}$ of sample was heated under reflux with $5 \mathrm{~mL}$ of $2 \%(\mathrm{~m} / \mathrm{v}) \mathrm{KOH}$ in absolute ethanol in a water bath at $50{ }^{\circ} \mathrm{C}$. The heating time was $2 \mathrm{~h}$ instead of $1 \mathrm{~h}$ as previously employed. ${ }^{27}$ After cooling, $10 \mathrm{~mL}$ of water was added to the mixture and the unsaponificable fractions were extracted twice with $10 \mathrm{~mL}$ of hexane. The organic phase was washed with $20 \mathrm{~mL}$ of water and the volatile solvent was evaporated under reduced pressure. The resulting residue was diluted to $5.0 \mathrm{~mL}$ with a $0.05 \mathrm{~mol} \mathrm{~L}^{-1}$ phosphate buffer solution also containing $10 \%$ $(\mathrm{m} / \mathrm{m})$ isopropanol and $10 \%(\mathrm{~m} / \mathrm{m})$ Triton X-100.

The human blood serum samples $(2.0 \mathrm{~mL})$ were obtained from a local clinical analysis laboratory, being analyzed as received.

\section{Flow diagram}

The multicommuted flow system shown in Figure 1 was operated according to the valves switching course in Table 1 for determination of free or total cholesterol. The manifold comprised six three-way solenoid valves: one

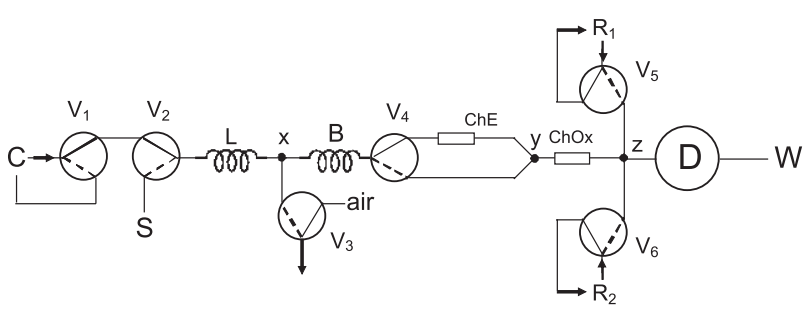

Figure 1. Flow diagram of the system employed for determination of free and total cholesterol: $\mathrm{S}$ : sample or reference solutions $\left(1.0 \mathrm{~mL} \mathrm{~min}^{-1}\right)$; C: carrier $\left(0.05 \mathrm{~mol} \mathrm{~L}^{-1}\right.$ phosphate buffer, $\left.\mathrm{pH} 7.0 ; 2.4 \mathrm{~mL} \mathrm{~min}^{-1}\right) ; \mathrm{R}_{1}$, $\mathrm{R}_{2}$ : luminol and potassium hexacyanoferrate(III) solutions, respectively, both flowing at $3.0 \mathrm{~mL} \mathrm{~min}^{-1}$; Vi: three-way solenoid valves; L: $25 \mathrm{~cm}$ sample loop; B: 25-cm coiled reactor; $\mathrm{x}, \mathrm{y}$, z: confluence points; W: waste; ChE: cholesterol esterase packed-bead reactor $(2.0 \mathrm{~cm} \times 3.0 \mathrm{~mm}$ id.); ChOx: cholesterol oxidase packed-bead reactor $(2.0 \mathrm{~cm} \times 3.0 \mathrm{~mm}$ id.); D: lab-made luminometer. Arrows indicate the points of actuation of the peristaltic pump. 
Table 1. Valves switching course for determination of free and total cholesterol

\begin{tabular}{llcc}
\hline Step & Action & Valves ON & time / s \\
\hline Free cholesterol & & \\
1 & Sampling & $\mathrm{V}_{1}, \mathrm{~V}_{2}$ and $\mathrm{V}_{3}$ & 7.5 \\
2 & Delay time & $\mathrm{V}_{4}$ & 10.0 \\
3 & Addition of reagents & $\mathrm{V}_{4}, \mathrm{~V}_{5}$ and $\mathrm{V}_{6}$ & 8.0 \\
4 & Measurement and washing & $\mathrm{V}_{4}$ & 20.0 \\
\hline Total cholesterol & & \\
1 & Sampling & $\mathrm{V}_{1}, \mathrm{~V}_{2}$ and $\mathrm{V}_{3}$ & 3.0 \\
2 & Delay time & 0 & 10.0 \\
3 & Addition of reagents & $\mathrm{V}_{5}$ and $\mathrm{V}_{6}$ & 8.0 \\
4 & Measurement and washing & \multicolumn{2}{c}{0} \\
\hline Sample replacement & \multicolumn{3}{c}{20.0} \\
1 & Sample replacement & $\mathrm{V}_{1}, \mathrm{~V}_{2}$ and $\mathrm{V}_{3}$ & 5.0 \\
2 & Washing & \multicolumn{2}{c}{$\mathrm{V}_{3}$} \\
\hline
\end{tabular}

valve for each solution managed $\left(\mathrm{V}_{1}, \mathrm{~V}_{2}, \mathrm{~V}_{5}\right.$ and $\left.\mathrm{V}_{6}\right)$, an auxiliary valve for sampling $\left(\mathrm{V}_{3}\right)$ and a valve employed for stream redirecting $\left(\mathrm{V}_{4}\right)$. In the position showed in Figure 1 , all valves were switched off and the carrier stream was propelled through $\mathrm{V}_{1}-\mathrm{V}_{2}-\mathrm{V}_{4}$ towards the flow cell while the reagent solutions $R_{1}$ and $R_{2}$ were recycled back to their vessels. In order to define the sample aliquots, valves $V_{1}$, $\mathrm{V}_{2}$ and $\mathrm{V}_{3}$ were simultaneously switched on, the carrier stream was sent back to its vessel and a sample aliquot was aspirated through $\mathrm{V}_{2}$ and $\mathrm{V}_{3}$ valves during $7.5 \mathrm{~s}$ (free cholesterol determination) or $3.0 \mathrm{~s}$ (total cholesterol determination). For free cholesterol determination, valve $\mathrm{V}_{4}$ was switched on during steps 2-4 and the sample zone was by-passed to the reactor containing $\mathrm{ChE}$. After a suitable delay time ( $8.0 \mathrm{~s}$ ), valves $\mathrm{V}_{5}$ and $\mathrm{V}_{6}$ were switched on during $8.0 \mathrm{~s}$ and the sample zone received the reagents $\left(\mathrm{R}_{1}\right.$ and $\mathrm{R}_{2}$ ) at the confluence point $\mathrm{z}$, being transported to the flow cell to measure the emitted radiation. For total cholesterol determination, the sample aliquot was transported towards the reactors containing $\mathrm{ChE}$ and $\mathrm{ChOx}$ by the carrier stream by switching all the valves off. Other steps were similar to those employed for free cholesterol determination. The temperature of the laboratory was maintained around $25^{\circ} \mathrm{C}$ with an air conditioner. All measurements were based on peak height and carried out in triplicate.

\section{Results and Discussion}

\section{General aspects}

A flow procedure based on multicommutation and chemiluminescence detection for the determination of free and total cholesterol is proposed. The enzymes were immobilized on silica beads, a suitable support in view of inertia to microbial attacks, stability and easy handling. The immobilization efficiencies were estimated by monitoring the protein concentration in the supernatant before and after the immobilization procedure. Concentrations of cholesterol oxidase (ChOx) and cholesterol esterase (ChE) in the solid support were $1.21 \mathrm{mg}$ protein per $\mathrm{g}(5.8 \mathrm{U})$ and $7.1 \mathrm{mg}$ protein per $\mathrm{g}(11.8 \mathrm{U})$, respectively. These values agreed with those previously reported in the literature. ${ }^{28,29}$

For total cholesterol determination, the hydrolysis of cholesterol ester by cholesterol esterase was the initial step (equation 1). The free cholesterol produced in this step was oxidized to cholest-4-en-3-one by cholesterol oxidase, with concomitant production of hydrogen peroxide (equation 2). The hydrogen peroxide produced was then quantified by oxidation of luminol in the presence of hexacyanoferrate(III) producing chemiluminescence (equation 3). Thus, the CL emission is proportional to the cholesterol concentration in the samples.

$$
\text { cholesterol esters } \stackrel{\mathrm{ChE}}{\longrightarrow} \text { cholesterol + fatty acids }
$$

\section{System optimization}

Chemical and hydrodynamic variables were evaluated to establish the best conditions for determination of both analytes. The effect of sample volume under the CL intensity for determination of free cholesterol was studied in the range from 50 to $150 \mu \mathrm{L}$, by varying the sampling time (Table 1, step 1) with a constant sample flow-rate $\left(1 \mathrm{~mL} \mathrm{~min}^{-1}\right)$. In this study, the sample loop and the delay time were fixed in $30 \mathrm{~cm}$ and $8.0 \mathrm{~s}$, respectively. The analytical signal increased linearly with the sample volume until $125 \mu \mathrm{L}$, in view of the lower sample dispersion, keeping almost constant for higher volumes. In this way, a sample volume of $125 \mu \mathrm{L}$ was selected for further experiments, being the sample loop reduced to $25 \mathrm{~cm}$. The aspiration was performed during $7.5 \mathrm{~s}$, time enough to completely fill the sample loop. On the other hand, taking into account the concentration of total cholesterol expected in the samples, the sample volume was fixed in $50 \mu \mathrm{L}$ for determination of this analyte. Time-based sampling was exploited in this step (3.0 s sampling time) to partially fill the sample loop. Sample dispersion in the sample 
loop (L) and the reactor coil (B) were adjusted to avoid previous sample dilution for determination of this analyte. If necessary, sample dilution could be carried out by the zone sampling approach, by directing part of the dispersed sample zone to waste through valve $\mathrm{V}_{3}{ }^{30}$

The carrier flow rate affects sample residence time in the enzymatic columns (and thus the conversion rate) as well as the dilution by the reagents at the confluence point $\mathrm{z}$. On the other hand, low flow rates of the carrier imply in longer delay times (Table 1, step 2) to assure reagent addition in the center of the sample zone. The effects of these variables were then simultaneously evaluated for determination of free and total cholesterol (Figure 2). For free cholesterol, equivalent $C L$ signals were observed for carrier flow rates of $2.4 \mathrm{~mL} \mathrm{~min}^{-1}$ or $3.0 \mathrm{~mL} \mathrm{~min}{ }^{-1}$ using a $10 \mathrm{~s}$ delay time. The effect of residence time in the enzymatic column was then less critical than the dilution at the confluence point, indicating that the conversion of cholesterol to cholest-4en-3-one and hydrogen peroxide (equation 2) is fast. This was also observed for total cholesterol and in spite of the highest response for a carrier flow rate of $1.8 \mathrm{~mL} \mathrm{~min}^{-1}$ and $14 \mathrm{~s}$ delay time, a flow-rate of $2.4 \mathrm{~mL} \mathrm{~min}^{-1}$ and a delay time of $10 \mathrm{~s}$ were selected taking into account the determination of both analytes using the same flow manifold. This compromise condition did not significantly hinder the analytical signal, which was only ca. $7 \%$ lower than the obtained in the optimum condition.

The effects of the other variables that affect the analytical response were evaluated employing a $500 \mathrm{mg} \mathrm{L}^{-1}$ cholesterol solution (Figure 3). Luminol concentration was investigated in the range from $1.0 \times 10^{-3}$ to $7.0 \times 10^{-3} \mathrm{~mol} \mathrm{~L}^{-1}$ (Figure 3a). The CL emission increased with luminol concentration until $5.0 \times 10^{-3}$, keeping constant for higher values in view of the self-absorption in excess of the reagent. Therefore, a $5.0 \times 10^{-3} \mathrm{~mol} \mathrm{~L}^{-1}$ luminol solution was used in subsequent work. The analytical signal increased with the

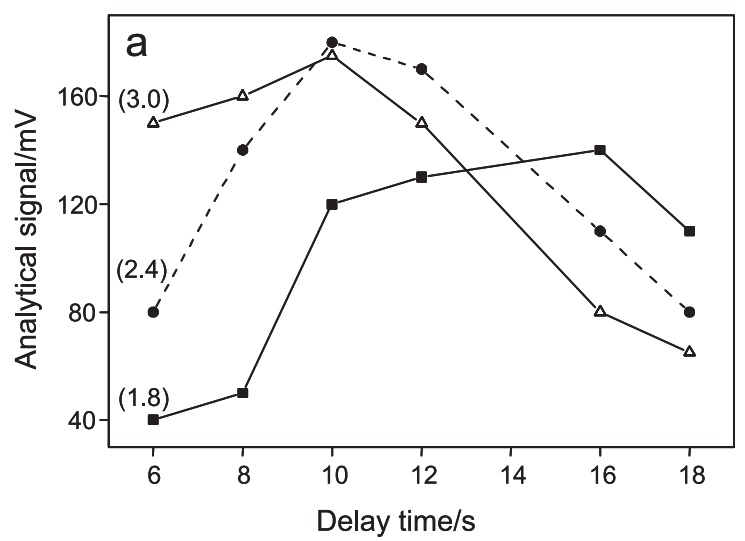

hexacyanoferrate(III) concentration up to $20 \times 10^{-3} \mathrm{~mol} \mathrm{~L}^{-1}$ and then slightly decreased (Figure $3 \mathrm{~b}$ ). This effect was caused by the absorption of the CL radiation by the colored hexacyanoferrate(III) solution, which did not compensate the catalytic effect. Then, the $20 \times 10^{-3} \mathrm{~mol} \mathrm{~L}^{-1}$ concentration was selected for the proposed flow procedure.

The influence of $\mathrm{pH}$ on the enzymatic reaction was investigated in the range from 6.5 to 8.0 employing $0.05 \mathrm{~mol} \mathrm{~L}^{-1}$ phosphate buffer solutions (Figure 3c). It was observed that maximum CL emission was achieved in the $\mathrm{pH}$ range from 7.0 to 7.5 , in agreement with previous works. Thus, pH 7.0 was selected for the proposed flow procedure. As a $0.05 \mathrm{~mol} \mathrm{~L}^{-1}$ concentration was enough to keep the $\mathrm{pH}$ constant, solutions with higher buffer capacity were not evaluated.

In addition to the solution concentration and flow rates, the reagent amount in the sample zone also depends on the switching times of the corresponding valves. The effect was simultaneously evaluated for both reagents in the range 5.0-10 s, employing solutions flow-rates of $3.0 \mathrm{~mL} \mathrm{~min}{ }^{-1}$ (Figure 3d). It was observed that the CL emission increased up to switching times of $8.0 \mathrm{~s}$ for both reagents, remaining constant to upper times. The volume of reagents employed under these conditions was $400 \mu \mathrm{L}$, which corresponds to $2.64 \mathrm{mg}$ of potassium hexacyanoferrate(III) and $0.35 \mathrm{mg}$ of luminol, respectively. The selected parameters are shown in Table 2.

\section{Effect of concomitant species}

Considering the application of the proposed flow procedure, the effect of several species, such as glucose and $\mathrm{Na}^{+}\left(1000 \mathrm{mg} \mathrm{L}^{-1}\right)$, urea $\left(200 \mathrm{mg} \mathrm{L}^{-1}\right)$, uric acid, $\mathrm{K}^{+}$and $\mathrm{Ca}^{2+}\left(100 \mathrm{mg} \mathrm{L}^{-1}\right)$, ascorbic acid $\left(0.1 \mathrm{mg} \mathrm{L}^{-1}\right), \mathrm{Cu}^{2+}$ and $\mathrm{Zn}^{2+}$ (0.01 $\left.\mathrm{mg} \mathrm{L}^{-1}\right)$ and $\mathrm{Fe}^{2+}\left(0.005 \mathrm{mg} \mathrm{L}^{-1}\right)$, was evaluated on the analytical signal for $2000 \mathrm{mg} \mathrm{L}^{-1}$ cholesterol. Ascorbic and

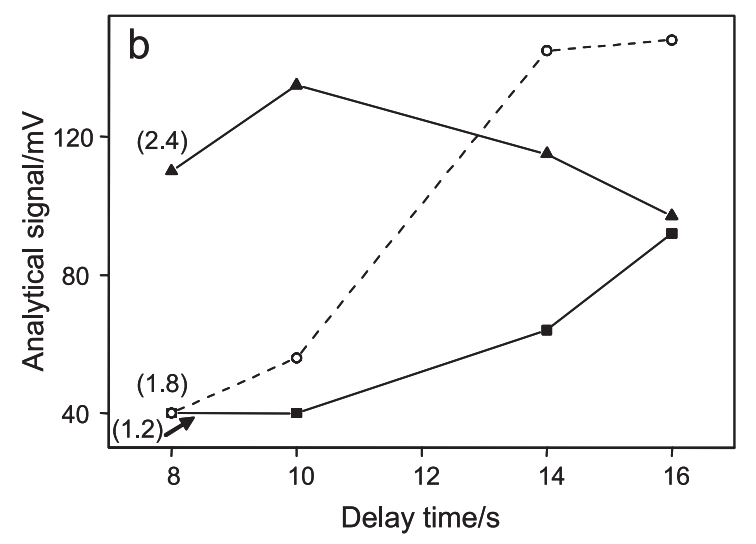

Figure 2. Effects of carrier flow-rate and delay time on the analytical signal for (a) free and (b) total cholesterol. Numbers between parentheses indicate the flow-rates in $\mathrm{mL} \mathrm{min}^{-1}$. 

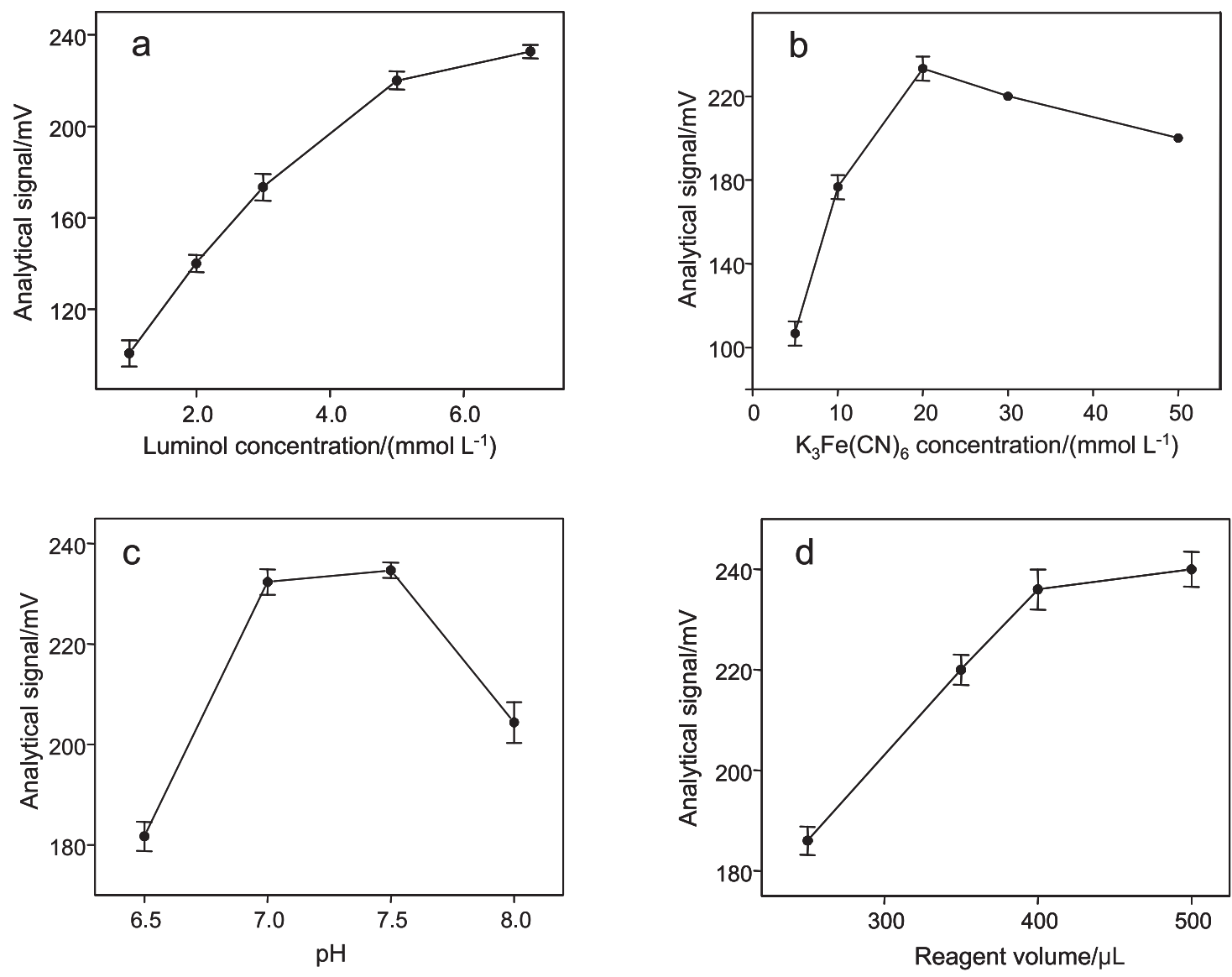

Figure 3. Effects of (a) luminol concentration; (b) hexacyanoferrate(III) concentration; (c) pH and (d) volume of reagents $\mathrm{R}_{1}$ and $\mathrm{R}_{2}$ on the analytical signal.

Table 2. Studied ranges and selected parameters for free and total cholesterol determination

\begin{tabular}{lcc}
\hline Parameter & Studied range & Selected value \\
\hline Sample loop $(\mathrm{L}) / \mu \mathrm{L}$ & $5.0-150.0$ & $125.0^{\mathrm{a}}$ and $50.0^{\mathrm{b}}$ \\
Coiled reactor / cm & $10.0-50.0$ & 25.0 \\
Carrier flow rate / $\left(\mathrm{mL} \mathrm{min}^{-1}\right)$ & $1.2-3.0$ & 2.4 \\
Delay time / s & $6.0-18.0$ & 10 \\
Luminol concentration / $\left(\mathrm{mL} \mathrm{min}^{-1}\right)$ & $1.0-7.0$ & 5.0 \\
$\mathrm{~K}_{3}\left[\mathrm{Fe}(\mathrm{CN})_{6}\right]$ concentration / $\left(\mathrm{mL} \mathrm{min}^{-1}\right)$ & $5.0-50$ & 20 \\
Phosphate buffer $\mathrm{pH}$ & $6.5-8.0$ & 7.0 \\
$\mathrm{R}_{1}$ and $\mathrm{R}_{2}$ volume / $\mu \mathrm{L}$ & $250-500$ & 400 \\
\hline
\end{tabular}

${ }^{\mathrm{a}}$ free cholesterol and ${ }^{\mathrm{b}}$ total cholesterol.

uric acids caused an inhibition of 11 and $12 \%$, respectively, at concentrations above the physiological. ${ }^{31}$ Despite $\mathrm{Zn}^{2+}$ ions caused an enhancement of CL emission ( $\mathrm{ca} .17 \%)$ when in the concentration of $0.01 \mathrm{mg} \mathrm{L}^{-1}$, the interference was not observed in the analysis of real samples, according to the results presented in the next section. This agreed with previous studies, ${ }^{32}$ in which the catalytic effect of zinc on the luminol oxidation was not observed in the presence of excess of another catalyst as employed in this work. Other species did not cause any interference on the determination of cholesterol.

\section{Analytical characteristics and application}

Transient signals for determination of free and total cholesterol, shown in Figure 4, demonstrate stable baselines and the repeatability of the results. The analytical response for free cholesterol determination was linear in the concentration range from 250 to $2500 \mathrm{mg} \mathrm{L}^{-1}$ and can be described by the equation: $\mathrm{I}=43.0+0.325 \times \mathrm{C}_{\text {Chol }}$ $(\mathrm{r}=0.999)$, in which $\mathrm{I}$ is the $\mathrm{CL}$ emission intensity in $\mathrm{mV}$ and $\mathrm{C}_{\text {Chol }}$ is the cholesterol concentration in $\mathrm{mg} \mathrm{L}^{-1}$. For total 

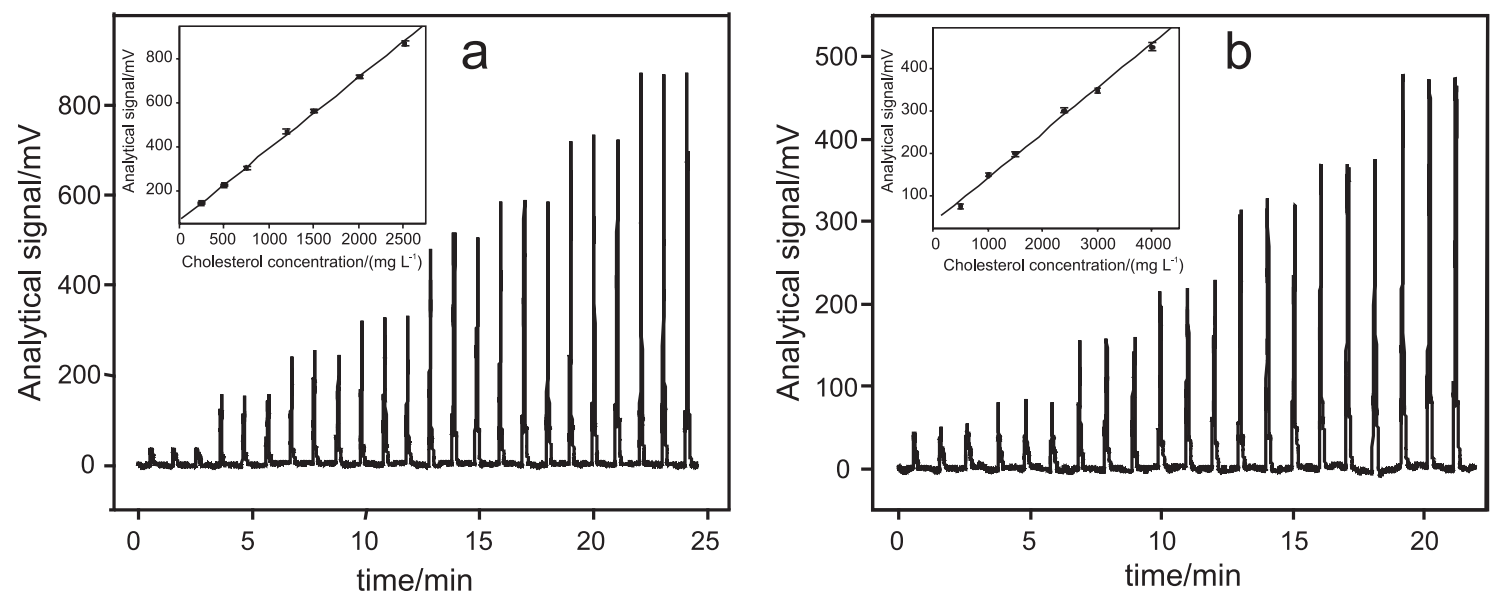

Figure 4. Transient signals for free (a) and total (b) cholesterol. The insets show the corresponding calibration graphs.

cholesterol determination, the analytical response was linear in the range from 500 to $4000 \mathrm{mg} \mathrm{L}^{-1}$, being described by the equation $\mathrm{I}=40.0+0.105 \times \mathrm{C}_{\mathrm{Chol}}, \mathrm{r}=0.998$. Coefficient of variation of $2.9 \%(n=10)$ and a sampling throughput of 55 determinations $\mathrm{h}^{-1}$ were estimated. The detection limit was estimated as $60 \mathrm{mg} \mathrm{L}^{-1}$ at the $99.7 \%$ confidence level.

After a $6 \mathrm{~h}$ working period, no baseline drift was observed and only a slight variation of $5.6 \%$ of the response

Table 3. Mean values and uncertainties $(n=3)$ for determination of free cholesterol in eggs $\left(\mathrm{mg} \mathrm{g}^{-1}\right)$ and total cholesterol in human blood serum $\left(\mathrm{mg} \mathrm{L}^{-1}\right)$ by the proposed and reference procedures

\begin{tabular}{lccc}
\hline Samples & \multicolumn{2}{c}{ Cholesterol concentration } & Relative error / \\
\cline { 2 - 3 } & Reference & Proposed & $(\%)$ \\
\hline White egg 1 & $14.7 \pm 0.2$ & $14.9 \pm 0.4$ & 1.3 \\
White egg 2 & $16.0 \pm 0.3$ & $15.7 \pm 0.3$ & -1.8 \\
Red egg 3 & $14.6 \pm 0.3$ & $14.3 \pm 0.5$ & -2.1 \\
Red egg 4 & $14.2 \pm 0.3$ & $14.6 \pm 0.5$ & 2.8 \\
Serum 1 & $819 \pm 5$ & $803 \pm 6$ & -2.0 \\
Serum 2 & $1316 \pm 9$ & $1293 \pm 9$ & -1.8 \\
Serum 3 & $2637 \pm 13$ & $2614 \pm 19$ & -0.9 \\
Serum 4 & $815 \pm 4$ & $795 \pm 5$ & -2.5 \\
\hline
\end{tabular}

for $2500 \mathrm{mg} \mathrm{L}^{-1}$ cholesterol solution was observed. After 15 days of use of each enzymatic reactor, the sensitivity decreased to $80 \%$ of its initial value. During this period, at least 400 assays were performed with each reactor.

Accuracy of the proposed procedure was assessed by determining free cholesterol in eggs yolk and total cholesterol in human blood serum samples. The obtained results were compared with those provided by a conventional spectrophotometric procedure using a commercial enzymatic kit (Table 3). Results obtained employing both procedures were in agreement at the $95 \%$ confidence level, with an acceptable range of relative error (lower than 3\%).

Analytical features of the proposed procedure were comparable with those achieved in previous works for determination of free and total cholesterol (Table 4). ${ }^{14-17}$ However, the multicommuted flow system allowed the determination of both analytes without system reconfiguration or previous sample dilution. The reagent consumption and waste generation were also minimized in view of the intermittent addition of the reagents and use of immobilized enzymes in a large number of assays.

Table 4. Analytical features of some procedures for free (A) and total cholesterol (B) determination

\begin{tabular}{|c|c|c|c|c|c|}
\hline Method & Linear range / $\left(\mathrm{mol} \mathrm{L}^{-1}\right)$ & $\mathrm{LOD} /\left(\mathrm{mol} \mathrm{L}^{-1}\right)$ & Sampling rate $/ \mathrm{h}^{-1}$ & $\mathrm{CV}(\%) ; \mathrm{n}$ & Reference \\
\hline FIA-spectrophotometric & $<1.8 \times 10^{-3}$ & $1.0 \times 10^{-6}$ & N.A. & $1.8 ; 10$ & 14 \\
\hline FIA-optical sensor & $5.0 \times 10^{-4}-8.0 \times 10^{-4}$ & $2.3 \times 10^{-4}$ & $\begin{array}{l}60^{\mathrm{A}} \\
30^{\mathrm{B}}\end{array}$ & $1.6 ; 5$ & 15 \\
\hline FIA-amperometric & $\begin{array}{l}4.1 \times 10^{-3}-5.2 \times 10^{-5 \mathrm{~A}} \\
7.8 \times 10^{-3}-7.8 \times 10^{-5 \mathrm{~B}}\end{array}$ & $3.5 \times 10^{-6 \mathrm{~A}}$ & $\begin{array}{l}80^{\mathrm{A}} \\
40^{\mathrm{B}}\end{array}$ & - & 16 \\
\hline FIA-amperometric & $1.0 \times 10^{-4}-5.0 \times 10^{-4}$ & N.A. & N.A. & - & 17 \\
\hline MCFA, CL detection with a photodiode & $\begin{array}{l}6.5 \times 10^{-4}-6.5 \times 10^{-3 \mathrm{~A}} \\
1.3 \times 10^{-3}-1.0 \times 10^{-2 \mathrm{~B}}\end{array}$ & $5.2 \times 10^{-5}$ & $55^{\mathrm{A}, \mathrm{B}}$ & $2.9 ; 10$ & this work \\
\hline
\end{tabular}

FIA: Flow injection analysis; MCFA: Multicommutation in flow analysis; N.A.: not available; A: free cholesterol; B: total cholesterol. 


\section{Conclusions}

The proposed flow procedure is robust and easily operated and has a great potential to clinical analysis. The procedure was implemented with inexpensive instrumentation by exploiting the multicommutation approach and a lab-made luminometer based on a photodiode. Low reagent consumptions and waste generation are other additional advantages. The method is simple, rapid and inexpensive and was successfully applied for the determination of free and total cholesterol in food and human blood serum samples.

\section{Acknowledgments}

The authors gratefully acknowledge fellowships and financial support from the Brazilian agencies FAPESP, CNPq and CAPES.

\section{References}

1. Bohac, C. E.; Rhee, K. S.; Cross, H. R.; Ono, K.; J. Food Sci. 1988, 53, 1642 .

2. Nogueira, G. C.; Bragagnolo, N.; Food Chem. 2002, 79, 267.

3. Amundson, M. D.; Mingjie, Z.; J. Biochem. Biophys. Methods 1999, 38, 43.

4. Krug, A.; Gobel, R.; Kellner, R.; Anal. Chim. Acta 1994, 287, 59.

5. Cleeman, J. I.; Lenfant, C.; JAMA, J. Am. Med. Assoc. 1998, $280,2099$.

6. Araújo, A. N.; Catita, J. A. M.; Lima, J. L. F. C.; Farmaco 1999, 54,51 .

7. Nakaminami, T.; Kuwabata, S.; Yoneyama, H.; Anal. Chem. 1999, 71, 1068.

8. Trettnak, W.; Lionti, I.; Mascini, M.; Electroanalysis 1993, 5, 753.

9. Amundson, D. M.; Zhou, M.; J. Biochem. Biophys. Methods 1999, $38,43$.

10. Situmorang, M.; Alexander, P. W.; Hibbert, D. B.; Talanta 1999, $49,639$.

11. Pires, C. K.; Reis, B. F.; Galhardo, C. X.; Martelli, P. B.; Anal. Lett. 2003, 36, 3011.
12. Nabi, A.; Rashid, A.; Yaqoob, M.; Anal. Lett. 1996, 29, 2281.

13. Huang, Y.; Zhang, C.; Zhang, Z.; Anal. Sci. 1999, 15, 867.

14. Pineiro-Avila, G.; Salvador, A.; de la Guardia, M.; Analyst 1998, $123,999$.

15. Krug, A.; Suleiman, A. A.; Guilbault, G. G.; Kellner, R.; Enzyme Microb. Technol. 1992, 14, 313.

16. Yao, T.; Sato, M.; Kobayashi, Y.; Wasa, T.; Anal. Biochem. 1985, $149,387$.

17. Adányi, N.; Váradi, M.; Eur. Food Res. Technol. 2003, 218, 99.

18. Borges, E. P.; Fernandes, E. N.; Rocha, F. R. P.; Reis, B. F.; Quim. Nova 2002, 25, 1191.

19. Leite, O. D.; Fatibello-Filho, O.; Vieira, H. J.; Rocha, F. R. P.; Cury, N. S. M.; Anal. Lett. 2007, 40, 3148.

20. Rocha, F. R. P.; Ródenas-Torralba, E.; Reis, B. F.; MoralesRúbio, A.; de la Guardia, M.; Talanta 2005, 67, 673.

21. Rocha, F. R. P.; Reis, B. F.; Zagatto, E. A. G.; Lima, J. L. F. C.; Lapa, R. A.; Santos, J. L. M.; Anal. Chim. Acta 2002, 468, 119.

22. Rocha, F. R. P.; Nóbrega, J. A.; Fatibello-Filho, O.; Green Chem. 2001, 3, 216.

23. Kiba, N.; Ito, S.; Tachibana, M.; Tani, K.; Koizumi, H.; Anal. Sci. 2001, 17, 929.

24. Ródenas-Torralba, E.; Rocha, F. R. P.; Reis, B. F.; MoralesRubio, A.; de la Guardia, M.; J. Autom. Methods Manage. Chem. 2006, art. No. 20384.

25. Weetall, H. H. In Methods in Enzymology; Mosbach, K., ed., vol. XLIV, Academic Press: New York, 1975, p. 135.

26. Hartree, E. S.; Anal. Biochem. 1972, 48, 422.

27. Jiang, Z.; Fenton, M.; Sim, J. S.; Poultry Sci. 1991, 70, 1015.

28. Tabata, M; Endo, J.; Murachi, T; J. Appl. Biochem. 1981, 3, 84.

29. Piñeiro-Avila, G.; Salvador, A.; de la Guardia, M.; Analyst 1998, $123,999$.

30. Araújo, A. N.; Lima, J. L. F. C.; Reis, B. F.; Zagatto, E. A. G.; Anal. Chim. Acta 1995, 310, 447.

31. Bishop, M. L.; Fody, E. P.; Schoeff, L.; Clinical Chemistry: Principles, Procedures and Correlations, Lippincott Willians \& Wilkins: Philadelphia, 2005.

32. Hu, Y.; Zhang, Z.; Luminescence 2008, 23, 338.

Submitted: January 14, 2010 Published online: May 27, 2010

FAPESP has sponsored the publication of this article. 